\title{
A new species of water vole from the Early Pleistocene of Southern Europe
}

Gloria Cuenca-Bescós, Jordi Agustí, Jaime Lira, Maria Melero Rubio, and Juan Rofes

Acta Palaeontologica Polonica 55 (4), 2010: 565-580 doi: http://dx.doi.org/10.4202/app.2009.0027

In the Early Pleistocene Red Lower Unit of the Sima del Elefante site (Sierra de Atapuerca karst complex, Burgos, Spain), levels TE9-TE13, dental and mandibular remains of an arvicoline are referred to as the new species Arvicola jacobaeus sp. nov. The new species has medium-sized hypselodont molars, with abundant cementum in the re-entrant folds, and thick enamel band with differentiation of the Mimomys-type. The occlusal morphology of M3 is simple. The dental morphology of the new species resembles that of Arvicola sapidus, though smaller. It is more derived, in size and morphology than the Middle Pleistocene species Arvicola mosbachensis. The morphologic affinities among Arvicola jacobaeus, Arvicola terrestris, and A. sapidus suggest a common ancestry. A preliminary phylogenetic analysis corroborates that Mimomys savini is the sister group of the Arvicola clade.

Key words: Mammalia, Rodentia, Arvicolinae, systematics, Pleistocene, Atapuerca, Spain.

Gloria Cuenca-Bescós [cuencag@unizar.es], María Melero-Rubio [mmelerorubio@gmail.com ], Juan Rofes [jrofes@unizar.es]. Aragosaurus-IUCA, Paleontología, Universidad de Zaragoza, 50009 Zaragoza, Spain; Jordi Agustí [jordi.agusti@icrea.es] ICREA. Institut de Paleoecología Humana. Universitat Rovira i Virgili. Pl. Imperial Tarraco, 43005 Tarragona, Spain; Jaime Lira [jlira@isciii.es] Centro Mixto UCM-ISCIII de Evolución y Comportamiento Humanos, c. Sinesio Delgado, 4, 28029 Madrid, Spain.

This is an open-access article distributed under the terms of the Creative Commons Attribution License (for details please see creativecommons.org), which permits unrestricted use, distribution, and reproduction in any medium, provided the original author and source are credited. 
Full text $(467.9 \mathrm{kB})$ 
